\title{
Diseases characteristic and control measurements for Chenopodium
}

\section{quinoa Willd}

\author{
Jinhui $\mathrm{Li}^{\mathrm{a}}$, Xueyong Zhou ${ }^{\mathrm{b} *}$, Haile Huang ${ }^{\mathrm{c}}$, Guowei $\mathrm{Li}^{\mathrm{d}}$ \\ Tianjin Engineering and Technology Research Center of Agricultural Products Processing, College \\ of Food Science and Bioengineering, Tianjin Agricultural University, Tianjin 300384, China \\ aemail: 1522610532@qq.com; 'email: zhouxueyongts@163.com; 'email: 453195554@qq.com; \\ demail: 490797650@qq.com. * Corresponding author: Xueyong Zhou.
}

Key words: quinoa; diseases characteristic; control methods

Abstract: Quinoa belongs to chenopodium which is annual dicotyledonous plant. It was domesticated in the Andes in South America. Since quinoa was introduced into China in 2011, it has been quickly planted in several provinces including Shanxi, Qinghai, Gansu, Sichuan and Jinlin. At the present, the quinoa products has been gradually known by more Chinese people. With the increase of planting area, the problems of plant diseases and pests become more and more severe. Unfortunately, the agricultural technology personnels in grassroots lack the controlling experience of quinoa diseases. In order to popularize the knowledge of quinoa disease, five kinds of pathogens and disease symptoms for quinoa are analyzed, and the controlling measures are put forward.

\section{Introduction}

Quinoa is a staple crop of the Andean highlands and some tropical countries. It belongs to the Chenopodiaceae family, genus Chenopodium. Its botanical name is Chenopodium quinoa Willd ${ }^{[1]}$. Quinoa is an annual self-pollinated dicotyledonous plants, the basic chromosome number $x=9^{[2]}$. It is an important traditional food for native Americans in South America and has been planted in 5000-7000 years ${ }^{[3]}$. Quinoa has a protein content that is higher, and an amino acid composition that is better balanced, than the major cereals ${ }^{[4]}$. In addition to high nutritional value, its important function is to prevent diabetes, high blood pressure, high blood lipids and other diseases ${ }^{[5-6]}$. Therefore, quinoa has been gained comprehensive attention around the world. Quinoa was introduced into Shanxi province, China in 2011, then it was quickly cultivated in other provinces, such as Qinghai, Gansu, Sichuan and Jilin province. With the increase of planting area of quinoa, however, the problems of pests and diseases have arisen.

In general, when a crop is newly introduced into another country or region, there are often without or only minor pests and diseases in the early stages, but the pests and diseases will increase as the year of cultivation increases. There are three reasons for the above results. Firstly, original pathogenic bacteria and pest eggs of the crop are introduced into a new country or region, and are gradually developed. Secondly, the same pathogenic bacteria or pests as the original places have already existed in the introduced region, nevertheless, they are not received attention due to a low occurrence level. Once these pathogenic bacteria or pests encounter the appropriate host, the diseases or pests will break out in large numbers. Thirdly, some diseases and pests of similar species will transfer to the introduced crops. Above analyses conform to the quinoa cultivation practice in China. In the initial two years for quinoa cultivation, the pests and diseases of quinoa are few, but the pests and diseases have gradually increased since the third year. Currently, the pests and 
diseases of quinoa have reached the point where they must control.

Professor Xueyong Zhou visited Iowa State University and studied the quinoa disease from September 2013 to March 2014. Based on the domestic and foreign experiences, the disease characteristics and controlling measurements of five kinds of quinoa diseases are provided, which can give guidance and reference for quinoa farmers.

\section{Characteristics of the main diseases of quinoa}

\section{Downy mildew}

Downy mildew is a sort of crop disease caused by the pathogenic bacteria Peronospora farinosa. García $^{[6]}$ first reported quinoa downy mildew in 1947. Downy mildew is one of the most widespread diseases of quinoa in Colombia, Peru, Bolivia and other countries. Although the suitable conditions for zygote germination of downy mildew is high humid and moderate temperature, studies have shown that quinoa downy mildew also occur in the plateau region with a average temperature of $6-10^{\circ} \mathrm{C}$ and an annual precipitation of $200-500 \mathrm{~mm}$. The main symptom of the disease is chlorotic lesions on the upper surfaces of leaves, forming white or purple lesions ${ }^{[7]}$. In the 1970s, agricultural experts in South American screened the disease-resistant varieties of quinoa. It was reported that UNTA60, UNTA63, UNTA116, UNTA140 and Tupiza of quinoa were highly resistance to the downy mildew; Kanccolla, Illimani, Ccoyto-1, UNTA97 and UNTA98 have moderate resistance; Sajama and Oxfam were sensitive to the downy mildew; UNTA18 and UNTA39 were highly susceptible ${ }^{[8]}$. In recent years, downy mildew of quinoa in China has become an important disease ${ }^{[9]}$.

\section{Brown stalk rot}

Brown stalk rot is caused by the pathogenic fungus of Phoma exigua var. foveata. The brown stalk rot of quinoa was first found on the Peruvian plateau in the 1974-1975 growing season ${ }^{[10]}$. This kind of pathogenic fungus likes cool and high humid environment. Pathogens are mainly located in the stem and inflorescence, the damaged parts by the disease was dark brown with a glassy edge.

\section{Root rot}

The symptom of the disease is black rot of quinoa root, supplying less water and nutrient from root to stems and leaves, resulting in yellow leaves or withered death. The pathogens of Quinoa root rot have not been clearly identified. It is generally considered that the root rot is a soil-borne disease caused by fungi, nematodes, bacteria. The disease will be relieved if the soil permeability increases.

\section{Leaf spot}

The leaf spot of quinoa was first described by Vilca in 1972 and the pathogen was identified as Ascochyta hyalospora ${ }^{[11]}$. It is apparently favored by high temperature. The fungus is seed borne and the first symptom is light spots of indefinite area on the leaves. At later stages pycnidia can be observed, and the leaves become dry and fall off. At present, leaf spot has become an important disease in the cultivation of quinoa in China ${ }^{[12-13]}$.

\section{Gray mold}

Quinoa gray mold was first observed in Cambridge. In the 1980s, quinoa was introduced to British, the variety Baer of quinoa was infected by Botrytis cinerea. Gray mold occurs on the stems and inflorescences of mature quinoa. Where the central axis of the inflorescence was affected, the secondary axes are liable to collapse. 


\section{Controlling measure}

\section{Quinoa downy mildew}

There are several methods to prevent the downy mildew. In the early stages, the wettable powder of mancozeb (available content 50\%) and Curzate (available content 72\%, E.I.Du Pont Company) can be used to control the downy mildew. Better effect can be achieved if the liquid can be sprayed to the back of leaves. For areas where there is a serious outbreak of downy mildew, quinoa should be sopped to cultivate for 3-5 years.

\section{Brown stalk rot}

At the beginning of the disease, the symptom can be controlled by the spray of carbendazim solution (50\% wettable powder should be diluted to 1000 times). In addition, mancozeb solution (70\% mancozeb should be diluted to 1000 times) also can be used, and the suitable dosage is 50-75 $\mathrm{kg}$ of mancozeb solution per $667 \mathrm{~m}^{2}$.

\section{Root rot}

The quinoa root rot can be controlled by hymexazol. The wettable powder of hymexazol (available content 50\%) is diluted to 1200-1500 times, then the solution is irrigated to the quinoa root. As a precaution, quinoa seeds can be soaked by thiram or carbendazim for ten hours before planting.

\section{Leaf spot}

Quinoa leaf spot can be controlled by diniconazole wettable power (available content 12.5\%). The suitable dosage for $12.5 \%$ diniconazole is 30 to $40 \mathrm{~g}$ per $667 \mathrm{~m}^{2}$ for spraying. The spraying time, however, should avoid the high temperature period at noon. In addition, mancozeb+cymoxanil also can be used for the leaf spot diseases.

\section{Gray mold}

The gray mold disease of quinoa can be controlled by liquid spaying of iprodione diluted for 1000 to 1500 times. Five days later, the pesticide should be used again. After twice spraying of iprodione, the symptom can be controlled effectively. For the severely affected areas, 5-6 kg carbendazim wettable powder (available content 25\%) can be sprinkled to the surface of soil before plowland.

\section{Conclusions}

Quinoa has not been introduced in China for a long time, currently the quinoa disease has not been fully recognized. According to the recent three years of quinoa planting experience, the diseases have a tendency to increase year by year. View from the current studies, quinoa diseases are mainly caused by fungi, few are caused by bacteria and viruses. In the present study, five kinds of pathogens and disease symptoms for quinoa are analyzed, and the controlling measures are put forward. The above controlling methods can give guidance and reference to quinoa farmers and agricultural technology personnels in grassroots.

\section{Acknowledgements}

The research was supported by the Innovative and Entrepreneurial Training Program for College Students of China (201610061166) and the Tianjin Key Projects of Scientific and Technological Support (17YFZCNC00220). 


\section{References}

[1] Michala J, Lucia M, Alexander D. Quinoa - a Review. Czech J. Food Sci., 2009, 27(2): 71-79.

[2] Gong $\mathrm{Bu} \mathrm{Za} \mathrm{Xi,} \mathrm{Wang} \mathrm{Mu,} \mathrm{Zhang} \mathrm{Chong} \mathrm{Xi.} \mathrm{Quinoa} \mathrm{biological} \mathrm{characteristics} \mathrm{in} \mathrm{Xizang.}$ Southwest China Agricultural Journal, 1997, 7(3):54-62.

[2] Vega-Gálvez A, Miranda M, Vergara J, et al. Nutrition facts and functional potential of quinoa (Chenopodium quinoa willd), an ancient Andean grain: a review. J Sci Food Agric 2010, 90: 2541-2547.

[3] Wang Li Ming, Ma Ning, Li Song, ect. Nutritional value of quinoa and its application prospect. Food Science and Technology, 2014, 35 (1): 381-385.

[4]Oshodi AA, Ogunbenle HN, Oladimeji MO. Chemical composition, nutritionally valuable minerals and functional properties of benniseed, pearl millet and quinoa flours. Int. J. Food Sci. Nutr., 1999, 50: 325-331.

[5] Jacobsen S E. The world wide potential for quinoa (Chenopodium quinoa Willd). Food Reviews International, 2003, 19(1-2): 167-177.

[6] García R G. Fitopatología Agrícola del Peru. Estación Agrícola de La Molina, Ministerio de Agricultura, 1947. Lima, Peru.

[7] OtazúV., SalasB. La podredumbre marrón del tallo de la quinua (Chenopodium quinoa) causadada por Phoma exigua var foveata. Fitopatologia, 1977, 12: 54-58.

[8] Otazú V., Aguilar A.P. C., Canahua M. A. Resistencia en quinua (Chenopodium quinoa) al milldiú (Peronospora effuse). Fitopatologia, 1976, 11: 47-49.

[9] Wei Yu Ming, Huang Jie, Gu Xian, ect. Technical specification for standardization cultivation of quinoa. Gansu Agricultural Science and Technology, 2015, (12): 77-79.

[10]Coaker T.H. Advances in Applied Biology, Volume X. Academic Press, INC, 1984, London.

[11] BoeremaG. H., MathurS. B., Neergaard P. Ascochyta hyalospora (Cook \& Ell.) comb. nov. in seeds of Chenopodium quinoa. Neth. J. Plant Pathol., 1977, 83: 153-159.

[12] Guo Xiao Feng. On the prospects and cultivation techniques of quinoa. Modern agriculture, 2015, (2): 61-63.

[13] Cheng Ming Suo, Liu Zeng Yu, Li Yu Chun. Plantation and cultivation techniques of quinoa. Henan Agricultural Sciences, 2013, (11): 43. 